\title{
CIVILIZAÇÃO E VIOLÊNCIA EM TERRAS PAULISTAS: NOTAS SOBRE O ROMANCE CHÃo BRUTO, DE HERNANi DONATO
}

\author{
Robson dos Santos ${ }^{1}$
}

\begin{abstract}
RESUMO
Neste artigo é desenvolvida uma análise do romance Chão Bruto, de Hernani Donato, buscando apontar como o autor elabora o texto mobilizando categorias como civilização e progresso, vistos como processos que encontram no mundo rural uma barreira física e cultural. A obra narra a ocupação do oeste paulista no início do século XX e as violências geradas na luta pela posse da terra. Para isso, Donato se ampara em noções como civilização e progresso como categorias implícitas ao desenvolvimento da trama. A análise do texto é realizada a partir da apreensão do confronto entre civilização e violência e da noção de estrutura de sentimentos, que tomamos para entender a permanência de imagens bucólicas em narrativas sobre o rural.
\end{abstract}

Palavras-chave: Civilização. Espaço rural. Romance. Violência. Modernização.

\section{CiVilization AND VIOLENCE IN SÃo PAUlo'S LANDS: NOTES ABOUT ON THE NOVEL CHÃo BRUTO, BY HERNANI DONATO}

\begin{abstract}
This paper purports to analyze Hernani Donato's Chão Bruto in order to show how the narrator elaborates the text by mobilizing categories such as civilization and progress, considered as physical and cultural barriers in rural areas. The book recounts the

Professor Doutor da Faculdade de Ciências Sociais da Universidade Federal de Goiás, Brasil. relvalins@yahoo.com.br
\end{abstract}


occupation of western São Paulo State in the beginning of the twentieth century and the violence that came about as a consequence of the struggle for land. In order to accomplish this, the author employs notions such as civilization and progress as implicit categories in the development of the plot. The analysis proposed here focuses on the confrontation between civilization and violence and the concept of structure of feelings, which will help understanding the permanence of bucolic images in narratives about the rural.

Keywords: Civilization. Rural lands. Romance. Violence. Modernization.

\section{CivilizaÇÃo E ROMANCE}

Este é o tempo de preparar a terra. O chão está úmido e fofo. E os dias, longos, mornos e claros debaixo de um céu estuporadamente azul. 0 vento corre apressado, rompendo favas, despetalando flores, derrubando cachos. Tem muito que semear o vento este ano, pois os bomens andam ocupados demais engraxando carabinas e carregando cartuchos para que possam ouvir o chamado da terra.

Hernani Donato, Chão Bruto.

noção de civilização possui diversos sentidos e passou a marcar as formas de
compreender a modernidade, sendo tomada inclusive como uma das realizações
mais destacadas desta. Em certa medida, a ideia de civilização é o fruto ideológico mais denso do iluminismo, ao passo que é um dos mais ambíguos e problemáticos. Associada inicialmente ao eurocentrismo, ao colonialismo, ao imperialismo e outros, o conceito de civilização busca, por outro lado, traduzir a incorporação pelos indivíduos de uma infinidade de valores e práticas sociais responsáveis por substancializar, moldar e orientar as sociabilidades e as instituições, bem como em um registro mais subjetivo, delimitar padrões físicos de disposiçã̃o do corpo.

Com essa palavra, a sociedade ocidental procura descrever o que the constitui 0 caráter especial e aquilo de que se orgulha: o nível de sua tecnologia, a natureza de suas maneiras, o desenvolvimento de sua cultura científica ou visão de mundo, e muito mais (ELIAS, 1994, p. 23).

É evidente que aqui não se trata de mobilizar tal categoria analítica com fins de aferir sua atualidade ou sustentar uma defesa integral de sua operacionalidade como categoria de análise sociológica. Porém, a ideia de civilização era atual e empregada

\footnotetext{
${ }^{2}$ A fortuna crítica ao conceito de civilização e seus associados, como evolução e progresso, é ampla. Para uma discussão sobre a origem do conceito de civilização e suas críticas, ver Williams (2000).
} 
pelos escritores em obras de vários momentos de nossa história literária, particularmente no período que nos interessa aqui, a década de 1950. Neste momento, o conceito de civilização e seus associados, como progresso, modernização, desenvolvimento etc., eram referências ideológicas e discursivas que balizava as formas e os conteúdos de diversas produções culturais (BOTELHO; BASTOS; BÔAS, 2008).

0 conceito de civilização é amplo e complexo. Na síntese de Raymond Williams, ele seria entendido como o progresso em sua fase consumada. Ainda de acordo com 0 autor, a partir do século XIX ele é usado como uma forma de definir a organização social, e também como conhecimento organizado e de refinamento dos hábitos e controle dos instintos, de refinamento e controle, o que seria criticado pelo romantismo (WILLIAMS, 2007). Apesar dos sentidos relativos que assumiu, o termo tem uma conotação de "contraste com a selvageria e a barbárie" (WILLIAMS, 2007, p. 84). Os sentidos e problemáticas relacionadas ao termo são inúmeros e inesgotáveis neste artigo. Fiquemos com essa noção de civilização como ordem social de controle oposta à desorganização, à ausência de regras e dominação da força violenta como referências gerais para captá-lo em seu uso nas representações literárias do rural.

Ao retomá-lo para analisar criações literárias, o intento é compreender como a noção de civilização é mobilizada na narrativa para expressar seu contraponto necessário: o que se representava nas obras como a "ausência de civilização", isto é, de espaços sem instituições e práticas civilizadas e reguladas. Em diversas narrativas literárias sobre o mundo rural ${ }^{3}$, tal ausência caracterizava os espaços e tempos, onde as normas, valores e costumes associados ao mundo civilizado não se realizavam. A civilização era compreendida em várias criações literárias como uma mancha que se estendia e ia se confrontando, tanto para ir tomando e caracterizando os espaços incivilizados, quanto por eles sendo derrotada. Esta é uma imagem comum nas narrativas sobre a tomada do interior, do rural, do sertão pelo litoral, isto é, pelas culturas portadoras da civilização, como em Os sertões, de Euclides da Cunha, ou Urupês, de Monteiro Lobato, entre outros (LIMA, 1999).

Neste bojo, como contraponto às próprias mudanças em curso, emergem entre as décadas de 1950 e 1960 - momentos de valorização do desenvolvimento e da modernização - produções caracterizadas por uma visão romântica da existência (RIDENTI, 2001). Isto é, que buscavam afirmar algum tipo de contraponto ao processo de modernização e racionalização que movimentava o país. Se a emergência do romantismo clássico foi também uma espécie de reação ao desenvolvimento do capitalismo e da civilização racionalizada (LOWY; SAYRE, 1995) é plausível analisar

\footnotetext{
${ }^{3}$ Pensamos, por exemplo, em Terras do sem fim (1943), de Jorge Amado; Filhos do Destino (1954) e Selva Trágica (1959), de Hernani Donato; Gabriela, cravo e canela (1958), de Jorge Amado; O tronco (1956), de Bernardo Élis; Vila dos Confins (1954) e Chapadão do Bugre (1965), de Mário Palmério.
} 
como as representações sobre a chegada da "civilização" em espaços antes inexistentes são marcadas por grandes contradições. Neste sentido, os espaços rurais emergem constantemente como o lugar em que tais situações conflitivas - civilização versus barbárie, progresso versus atraso, liberdade versus limitação - irrompem com frequência e são tomados como elementos de construções literárias por diversos autores.

É sob tais problemáticas que propomos aqui analisar o romance Chão Bruto, de Hernani Donato. Esta obra constitui uma formalização estética sobre a ocupação do oeste paulista no início do século XX e os conflitos decorrentes. Para isso, tomamos as narrativas literárias como criações que se constituem "a partir de materiais não literários, manipulados a fim de se tornarem aspectos de uma organização estética regida pelas suas leis próprias" (CANDIDO, 2004, p. 10). Não se trata de simples reflexo ou descrição "verdadeira" de fatos históricos, mas de uma construção literária que tem em uma realidade particular, o desenvolvimento do capitalismo em um tempo e região do país, os pontos de referência centrais para a elaboração do enredo, personagens, conflitos, tempo e espaço do romance, isto é, de materiais literários.

Publicado em 1955, o romance Chão Bruto (DONATO, 1980) - que teve até 1976 um total de 7 edições - comporta uma narrativa na qual o espaço rural aparecia como ambiente em processo de modelagem pelas forças da civilização e o progresso capitalista, mas isso ocorria com o recurso à violência brutal que, contraditoriamente, almejava cumprir um papel civilizador. 0 tema do confronto entre modelos de cultura era caro ao escritor e aparece em outras de suas obras, como Filhos do Destino e Selva Trágica, todas marcadas pela referência a uma realidade dada, que referida para a construção literária.

\section{UM ESCRITOR PLURAL}

Hernani Donato ${ }^{4}$ representa um tipo constante de escritor no Brasil, próximo àquilo que Sérgio Miceli (2001) bem definiu como polígrafo, isto é, agentes intelectuais

\footnotetext{
${ }^{4} 0$ autor era filho de imigrantes italianos. Nasceu em Botucatu, interior do Estado de São Paulo, em 1922. Atuou em diversas profissões intelectuais, tais como jornalista, escritor, historiador e editor, distanciandose, dessa forma, do processo de especialização intelectual. Estudou Sociologia, no início da década de 1940, na Escola de Sociologia e Política. Foi servidor público municipal e federal. Deixou o curso de sociologia para dirigir uma expedição que tinha a finalidade de levantar, até o Paraguai, roteiro do caminho pré-cabralino que os indígenas chamavam de Peabiru, a serviço do governo. Foi membro da Academia Sul-Mato-Grossense de Letras do Instituto Histórico e Geográfico de São Paulo (do qual foi seu Presidente por duas gestões sucessivas); membro da Academia Paulista de História e da Academia Paulista de Letras. Atuou na imprensa em vários jornais e revistas. Atuou como roteirista na TV Tupi, Record, Nacional (Globo), onde foi produtor de programas culturais. Possui mais de 60 livros publicados, incluindo contos, romances, biografias e historiografia, livros infanto-juvenis. Seus principais romances são: "Filhos do Destino" (publicado em 1954), "Chão Bruto" (publicado em 1956), e "Selva Trágica"
} 
que transitam na produção de formas discursivas diferenciadas, como o jornalismo, a literatura, a biografia, o ensaio histórico etc., para sua reprodução social, sendo impossível, em função da própria configuração do campo literário, viverem exclusivamente de ficção.

Donato inicia sua carreira intelectual na sociologia, tendo frequentado por alguns anos o curso na Escola Livre de Sociologia e Política de São Paulo, na década de 1940. Sua interrupção da carreira foi motivada, no terceiro ano do curso de Sociologia, segundo entrevista realizada com o autor, pelo interesse em fazer reconstruções históricas, sobretudo sobre a história de ocupação do interior do Brasil, a partir das narrativas bandeirantes, que passa a reconstruir e recontar em textos para a imprensa. Posteriormente segue carreira no campo publicitário e editorial, que concilia com as atividades de romancista, historiador, executivo e autor de livros infantis.

É arriscado atribuir à formação inicial e incompleta em sociologia uma influência determinante em suas construções literárias, mas, mais arriscado ainda seria ignorá-la por completo. 0 tema histórico e a descrição de processos de transformação social são fortes o suficiente nas obras do autor para justificar uma atenção maior a tal experiência. Donato busca conferir à literatura uma missão analítica, crítica e de denúncia, por meio de uma reconstrução minuciosa de práticas e lugares. 0 mundo social que elege para isso é aquele que vislumbrou e vivenciou tangencialmente durante sua infância no interior do Estado de São Paulo, como filho de imigrantes italianos que trabalhavam com decoração de igrejas e em viagens pelo interior do Mato Grosso do Sul.

A obra do escritor é expressão maior desta pluriatividade que o marca. Seus textos englobam além de romances, literatura infantil, dicionário de lutas sociais, biografias, roteiros de cinema etc. Algumas de suas obras foram inclusive produzidas como filmes, como Selva Trágica (dirigida por Roberto Farias, em 1963) e o próprio Chão Bruto, levada aos cinemas em 1958 (dirigida por Dionísio Azevedo e com roteiro do próprio Donato) e em outra versão em 1976.

\section{ROMANCE E MUDANÇA SOCIAL}

No romance Chão Bruto, o progresso tem como uma de suas consequências a civilização. Isso não quer dizer que ele seja feito sob os métodos "civilizados". "Não agrada, é certo, mas o progresso cobra seu preço onde ergue morada" (DONATO, 1980, p. 136). É ele que impõe as sociabilidades "modernas" e "civilizadas". Mas os alvos do

(publicado em 1959). Donato faleceu em 2012, aos 90 anos, em São Paulo. Até os 89 anos trabalhava como conselheiro de editoras [fontes: textos e informações extraídos e entrevista com o autor e dos portais eletrônicos da Academia Paulista de Letras e Academia Sul-Matogrossense de Letras: $<$ www.academiapaulistadeletras.org.br e www.acletrasms.com.br>_(SANTOS, 2011). 
progresso são refratários, inadequados, os odres são velhos e não suportam os vinhos novos. Assim, paradoxalmente, em muitos casos não são as práticas civilizadas que produzem a civilização, mas é a violência bruta que deve conduzir o processo. A efetividade da civilização, principalmente no espaço rural da narrativa, só encontra entraves. Chão Bruto ${ }^{5}$, de Hernani Donato, pode ser lido como uma alegoria deste processo visto como o confronto entre a civilização e a barbárie, da permanência do atraso, da restrição das ações e da opressão que caracterizavam o mundo rural.

A ação se passa no interior de São Paulo, no período de ocupação do oeste do Estado, mais especificamente a região do Pontal do Paranapanema, na primeira década do século $X X^{6}$. A narrativa se concentra nos conflitos agrários entre posseiros, grileiros e fazendeiros pelas terras ainda não ocupadas na região e que se encontram em processo de valorização, motivada pela construção da ferrovia Sorocabana que se estende, no início do século XX pelo interior do Estado e altera as relações socioeconômicas existentes ${ }^{7}$. Os agentes diretos da violência são jagunços desprovidos de propriedade e de vínculo direto com o trabalho na terra.

$\mathrm{Na}$ obra, a terra, antes das promessas econômicas que o progresso anuncia, é paisagem habitada por matutos e caipiras, lançados em uma vida singela, dependente diretamente da natureza ${ }^{8}$ e que remete sempre a um passado longínquo positivado, diferente do presente da narrativa, sempre tingido de violências e explorações. Em Chão Bruto, aquilo que Candido (1975) chamou de sistema caipira, encontra-se em fase de superação. A caracterização destes modos de existência, que estão em processo de dissolução, é dada logo no início da narrativa.

Assim estavam as coisas nas terras do grande Pontal! Os mapas diziam delas - 'sertão desconhecido'. E esse aviso punha tremuras de doença nos magríssimos caminhos estendidos sabe Deus por quem no rumo do Mato Grosso. Em torno, o vazio de homens, matas pejadas de frutos, palmitais

\footnotetext{
${ }^{5}$ A edição de Chão Bruto utilizada para a análise é a sétima, de 1977, da editora Hucitec.

${ }^{6}$ Para um panorama geral sobre as fases de ocupação e as lutas na região do Pontal do Paranapanema, sob uma perspectiva histórica e geográfica, ver Sobreiro Filho (2012).

${ }^{7}$ Uma análise histórica e geográfica mais detalhada sobre a expansão das ferrovias no interior do Estado de São Paulo, ver a dissertação de Stefani (2007).

${ }^{8}$ É verdade que toda vida depende da natureza. A natureza não é, necessariamente, o pré-humano, o précultural que se encontra intacto antes da chegada das relações sociais e culturais trazidas pela humanidade. Natureza e cultura se realizam de forma integrada, como instâncias da realidade que se constituem de forma relacional, dialética e unificada (EAGLETON, 2005). No entanto, no plano das representações literárias e especificamente no romance Chão Bruto, a estratégia narrativa consiste em opor realidades socioculturais: o passado marcado por uma vida reproduzida a partir da extração direta e na simbiose com a natureza e o presente da narrativa, quando a especulação das terras, a chegada das ferrovias, de obras, do Estado, isto é, construções humanas sobre a natureza, afastam os indivíduos daquela vida passada.
} 
sem fim, rios ferventes de peixe, caça grossa, céu rasgado e um silêncio bom pra se comer, dormir, viver.

Mas 0 que havia de melhor era a gente pouca. Caipiras mansos, com 0 umbigo enterrado por ali, os olhos cheios, as mãos vazias e o coração de quem não tem reclamos a fazer contra a vida. A terra dava tudo sem exigir coisa que fosse [...] Não senhor! A vida não cobrava pela paz que oferecia. 0 passado não pesava e o futuro não preocupava (DONATO, 1980, p. 10).

0 espaço é descrito como marcado por uma natureza abundante e que possibilita uma vida simples, mas farta. Aqui emergem os aspectos mais aparentes daquilo que Raymond Williams denominou estrutura de sentimentos bucólica, analisada como presente na literatura inglesa ao logo do processo de industrialização e que se marcava pela produção de imagens literárias que lançavam para um passado remoto, os velhos tempos, a existência de uma vida melhor, harmônica, tendo a natureza abundante como paisagem (WILLIAMS, 2011). Um rural dominado por uma temporalidade própria, por um vínculo intenso com a terra profícua, em que se plantando tudo dá; um rural imune aos grandes conflitos sociais, pois é refratário aos grandes interesses capitalistas, que convertem a terra em valor de troca, em fonte de especulação.

Herdavam os ranchos, os nomes, as roupas, as inimizades. E uma ideia vaga de que longe, para o leste, havia cidades, trens de ferro, cafezais, soldados, impostos, fiscais do governo - isto é, um mundo francamente desprezível, ao encontro do qual jamais iriam.

Mas de repente o tal mundo estranho investiu contra eles. Começou quando o risco no campo e o furo no mato se transformaram em caminho para as boiadas tangidas de Mato Grosso. Os bois e os seus condutores passavam de corrida, atropelados. Enganada por essa pressa a gente "posseira" entendeu de tirar vantagens (DONATO, 1980, p. 10).

0 rural vai se configurando na narrativa como um campo de batalhas à medida que os interesses econômicos vão se tornando mais densos e a terra alvo da valorização. Aos poucos, durante a trama, o espaço físico intocado dá lugar às relações sociais que 0 transformam, à temporalidade trazida pelo progresso e a uma nova configuração do meio. Disso resulta que, no plano do espaço, a limitação que a natureza impõe à ação dos personagens é substituída pela redução do horizonte social, trazida pela exploração econômica, a propriedade e a violência. Os novos fatores produtivos e a busca pela riqueza passam, aos poucos, a remodelar e dominar a natureza antes vista como pouco alterada. Esta reconfiguração, porém, é feita naquele ambiente, exclusivamente pela linguagem da força bruta e pelo poderio de fazendeiros com seus exércitos privados. 
As possibilidades da civilização, de uma vida democrática, de relações racionaislegais se efetivarem no Pontal são problemáticas, de acordo com o desenvolvimento da trama. 0 espaço natural pouco tocado é convertido em espaço social cobiçado como mercadoria, e este substitui a limitação atribuída ao ambiente físico e passa a ser cenário de relações sociais confinadas à luta agressiva pela terra. A harmonia, aos poucos, passa a ser vista como um atributo do passado, quando a vida mais próxima com a natureza era predominante.

Os confrontos violentos se agudizam à medida que as obras de construção da linha férrea se ampliam e os indícios acerca da sua chegada naquele espaço se tornam mais concretos.

A turma de locação da Sorocabana despegou-se do Paranapanema junto do Salto Grande e enveredou pelo sertão. Um bando de engenheiros arrastando um despropósito de gente e de material: carros, instrumentos, barracas. Estão riscando o sertão e endoidecendo de cobiça e de medo ricos e pobres. Para os ricos maiores ganhos, para os pobres trabalho e cuidados (DONATO, 1980, p. 87).

Escrito em 1956, o livro almeja constituir um western, povoado de tiroteios, fazendeiros, homens armados, honra e amores passados no interior das lutas pela expansão da fronteira. Os personagens estão ligados pela terra, mais especificamente pela pequena vila que se forma às margens de um porto fluvial. É por aí que a narrativa sempre passa diante dos olhos céticos de Suindara, um velho homem que aluga cavalos e pasto para os animais dos tropeiros que transitam por ali. Suindara é um dos rescaldos dos velhos tempos. Mas a sua casa é apenas um dos espaços de fluxo das disputas. A outra é a da prostituta Xaica. Ambos representam observadores das violências e barbaridades que se impetram em nome do progresso e pelas terras. É na imensidão destas que a trama se passa. Entre casas isoladas, vastos descampados onde se travam batalhas sangrentas e, por vezes épicas, frutos da expansão para o oeste.

Os rios correm, a boiadeira leva o seu gado, a Sorocabana assenta os seus trilhos. Um bispo sai a crismar os filhos do mato, os madeireiros começam a despir a terra, a escolta de capturas escreve a tiros os capítulos da sua legenda. 0 posseiro perde a terra em que nasceu e onde esperava morrer (DONATO, 1980, p. 63).

Chão bruto, cujo subtítulo é a conquista do extremo oeste paulista, é um romance com intenções históricas, isto é, de tirar da matéria social os elementos para uma construção literária. Por isso, não deixa de ser relevante destacar que a região do Pontal ainda permanece em São Paulo como um dos principais espaços de conflitos por 
terra, com forte presença de movimentos sociais. É evidente que a obra comporta uma referência associada ao processo histórico que toma como inspiração. Mais do que isso, porém, é importante buscar apreender o tipo de olhar, de construção que o narrador faz do espaço e das relações que lá vislumbra. Segundo o próprio Donato, em entrevista concedida em 2010, a motivação inicial para o romance surgiu de uma viagem feita ao Mato Grosso do Sul. Ao passar pela região do Paranapanema, encontrou um antigo amigo de infância que havia se tornado jagunço. A conversa com tal personagem alimentou a intenção de Donato escrever um romance histórico sobre a conquista do interior paulista, tal como havia feito em seu romance anterior Filhos do Destino, de 1954, que versava sobre as plantações de café e a imigração europeia e japonesa.

A narrativa de Chão Bruto se inicia com o relato culpado do pistoleiro Lino, por ter cometido mais um "crime de encomenda", assassinando posseiros que se recusavam a aceitar os termos impostos por um fazendeiro local. A consciência cindida do jagunço denota sua condição ambígua no espaço social: seu trabalho é matar, mas sabe que não é proprietário de terras, em um espaço onde elas valem muito, logo sua vida vale pouco mais ou tanto quanto a vida dos que ele executa. Xaica, a prostituta da narrativa, busca acalmá-lo, ao passo que localiza sua condição determinada pela teia de relações que aquele universo sustenta: "Feche os olhos e não pense no que se passou. Você não teve mais culpa do que o patrão. Aquelas não foram mortes que aproveitassem aos pobres. A ele sim, rende quem sabe quantos alqueires dessa terra amaldiçoada" (DONATO, 1980, p. 7).

Neste ambiente, é preciso acumular com rapidez, pois a chegada da ferrovia significa uma valorização das propriedades, haja vista que ela possibilita a ampliação dos espaços ocupados com o café e a criação de gado. Na ausência do Estado e aparelhos reguladores pretensamente impessoais, a corrida para a apropriação das terras aprofunda a incivilidade e as restrições da violência bruta, distintamente das promessas de liberdade que acompanhavam os discursos da modernização trazidos pela ferrovia.

Nesse contexto, o capitão Paulo, fazendeiro da região, se lança em uma ensandecida guerra para expulsar os últimos posseiros e dominar a área. Aí reside um dos eixos do romance. Um destes posseiros é Libêncio, pai de Sinhana, que é uma jovem moça que nutre uma paixão por Lino, um dos principais capangas do Capitão Paulo. E é justamente a Lino que é atribuída a tarefa de expulsar o posseiro.

- Isso é a posse da Água da Cotia. Que requeri faz seis meses. Botei fora por bem os posseiros que estavam ali. Só ficou o Libêncio, pai da sua amada. Teimoso como burro frouxo. Reservei esse negócio para você. Sei que por seu gesto você não iria. Mas vai porque quero que vá. Liquide o assunto com o homem de modo que na segunda-feira ele não esteja mais ali (DONATO, 1980, p. 16). 
As sociabilidades que se impõem são as orientadas pelo poderio econômico. Nesta etapa do processo civilizador inexistem espaços ou possibilidades para o amor. Aqui se trata de um dos aspectos daquilo que temos nomeado como narrativa da limitação. 0 olhar expresso na estrutura de sentimentos bucólica que orienta a representação do passado da narrativa é substituído por um conjunto de impossibilidades à medida que as relações sociais vão remodelando a natureza.

0 personagem Lino encontra-se em uma posição intermediária e dividida: ao mesmo tempo em que anseia reconstruir sua vida superando seu passado de jagunço, vive os paradoxos de ter que continuar no ofício, dado o fato de não ter outra inserção naquela estrutura social. Seu dilema é entre a falsa liberdade que a vida de jagunço lhe oferece e a aceitação de sua condição subordinada de sujeito desprovido de posses, pois se trata de um simples trabalhador rural. Em ambas as condições se vê restrito pelo mundo social que se constitui naquele espaço rural. Na primeira, porém, ocupa determinada posição de prestígio e reconhecimento social. 0 que torna ainda mais complexa suas escolhas, haja vista que implicam em perda de prestígio e reconhecimento, bem como de decadência socioeconômica.

\section{O PROFESSOR: UM ESCLARECIDO OU UM JAGUNÇO EM FORMAÇÃO?}

A restrição existente naquele mundo rural aparece na narrativa em situações distintas. 0 amor, as leis, as próprias amizades estão sob o risco permanente de dissolução caso se disponham frente aos interesses de acumulação de terra. Isto fica patente ao acompanharmos a história de Caio, o professor do povoado. É de suas reflexões que emerge uma síntese de uma visão contida na obra sobre o mundo rural do Pontal, espaço da narrativa.

Dois anos vividos ali acabaram com tudo nele: estímulo, vocação, coragem! Quanto mais fugia ao mundo ambiente, mais se desencontrava na vida que percebia na terra, nas coisas, na gente. Descobrira o porquê do desencontro: era homem educado para acreditar no dia seguinte, no ano que vem, numa pirâmide regular de autoridade e de responsabilidade. E aquela terra, aquele tempo e aquela gente viviam deslembrados do ontem e só preocupados com o dia de hoje. A vida humana não valia uma pichorra trincada e os caminhos das criaturas raramente seguiam direções paralelas (DONAT0, 1980, p. 19).

Caio indica a fragilidade do processo de modernização e da própria civilização no espaço da narrativa. Trata-se de um ambiente que tudo limita e impede. 0 passado daquele mundo rural limitava por ser restrito às possibilidades da natureza e do 
isolamento; o presente limita por ser subordinado à violência, aos interesses econômicos e à vida provinciana. Como ele entende que sua condição urbana exterior já tinha lhe "civilizado", sua trajetória passa a ser inversa a do espaço em que vive: ele vai se brutalizando pelo meio, em uma espécie de regressão dos caracteres civilizados. A imagem é a de um indivíduo que, ao se deslocar do habitat urbano se "simplifica" e se livra das cascas civilizadas, vendo manifestar-se uma natureza fragilmente contida.

A educação que Caio professa se acomoda aos termos do Pontal do Paranapanema. 0 meio determina a cultura, modelando-a e encapsulando-a nas suas restritas fronteiras. Sua posição irrompe no romance como a transposição para a narrativa da explicação determinista do ambiente físico. Na composição do narrador, Caio é o analista, uma espécie de intelectual em um mundo bárbaro e que vai aos poucos sendo remodelado pelo espaço e suas relações.

Depressa 0 impacto tornara-se espetáculo. A brutalidade justificou-se aos seus olhos com a absolvição da necessidade. Os homens eram como eram porque a época e a região talhavamnos por um figurino que nenhuma outra jamais conhecera. A um certo momento os pacíficos compreendem que também desempenham um papel e se não atuassem os valentes ficariam sem ação. Nas tragédias como nas comédias é necessário o espectador. Quis ficar de lado e assistir. Mas o pitoresco tomou conta dele: o bruxedo da terra bárbara entorpeceu gozosamente a rebeldia de civilizado. Descobriu coisas:

- Tem razão para beber tanto! 0 clima, a solidão, o meio... Estão certos quando são desconfiados, - a vida não é fácil e a confiança é quase somente uma palavra que se lê nas cartilhas, sem qualquer significado na vida prática. E também não são vadios, não são acomodados às necessidades da natureza. Se a vida exige pouco, por que há de o homem preocupar-se além da natureza?! Nada, não! (DONATO, 1980, p. 20).

0 professor incorpora a posição de um "porta-voz" da civilização. Mas, note-se que aqui sua compreensão do processo soa frágil. Ele mesmo já é alguém absorvido. É como se a obra apontasse que a própria civilização se adéqua, se acomoda ao ambiente bruto, à violência generalizada e à sanha destrutiva da expansão das fronteiras mercantilizáveis. Nada pode prosperar. Mesmo os resquícios de civilização, dos quais as tentativas de análise de Caio são indicativas, já denotam suas estratégias. Como tentamos argumentar, Chão Bruto descreve um rural como espaço do atraso, que funciona como um verdadeiro dique social e geográfico para as instituições da modernidade. 


\section{A TERRA ENTRE O AMOR, A HONRA E A RACIONALIDADE ECONÔMICA}

0 progresso aqui não é apresentado como o portador de potencialidades positivas e/ou democráticas. E a própria dualidade que se estabelece entre a tradição e a modernidade, o atraso e a civilização se revela muito mais na oposição entre a vida estática e a dinâmica da violência. Infere-se daí que, em Chão Bruto a noção de civilização e de progresso se associa à violência, ou se faz por meio desta. Na narrativa isto não conflui, porém, na ideia clássica de certo romantismo de que a felicidade só poderia estar num retorno ao bucólico. Se existe um viés romântico na obra, ele se aproxima da tipologia de Lowy e Sayre (1995) denominaram de resignado, que engloba uma visão onde a modernidade é um mal incontornável. Assim, o retorno ao passado (antes da ferrovia) se fazia evidentemente impossível no quadro de progresso que a conquista do "oeste" busca significar. 0 que o narrador construído por Donato parece ressaltar é a violenta ganância que o "progresso" fomenta, não que o "progresso" seja necessariamente ruim, dado que ele civiliza. Contudo, em Chão Bruto ele é apresentado como uma força orientada exclusivamente pelos interesses monetários, não é acompanhado de qualquer pretensão educacional, cultural, democrática ou qualquer signo "iluminista".

Outro representante da "civilização" na trama é o advogado Rui, que é contratado para acertar "os papéis e os números" do fazendeiro Paulo, que é o principal proprietário de terras da região e um dos agentes centrais da violência. A presença de Paulo é vista inicialmente com desconfiança pelo coronel: "É eficiente demais, manso e polido em excesso - não pode ser um homem como o serviço precisa!" (DONATO, 1980, p. 60).

Mas sob o manto aparente de civilidade excessiva trazida por Rui reside uma lógica de interesse, de expropriação que não se serve das mesmas ferramentas da violência física, que recorre a meios distintos e mais modernos para a realização dos mesmos intentos: tornar-se proprietário de terra. Sua tática não recorre às armas, mas aos estratagemas judiciais e aos golpes econômicos. Ele é o agente da dominação burocrática, que recorre aos subterfúgios formais para conseguir realizar seus interesses.

Neste universo, porém, alguns resistem à lógica de conversão da terra em mercadoria e se apegam a ela buscando manter suas dimensões telúricas. A resistência do velho posseiro Libêncio às violências impetradas e sua obstinação em não aceitar passivamente aos imperativos do Capitão Paulo, juntamente com a paixão de Sinhana por Lino, constituem um dos universos gravitacionais e alegóricos destas questões.

- Mas pai... mas pai... e se for mesmo ele que o capitão mande pra cá? Que é que fazemos, hem, pai? 
Libêncio morde o lábio, olha o céu estrelado e descobre que começa a odiar o homem que a filha adora.

- Então, pai? Se for ele? Não posso, não quero gostar, mas gosto dele, pai!

Libêncio escorre uma das mãos para debaixo do banco e certifica-se do peso e da frieza da carabina embalada. 0 ódio contra o homem que há de vir, cresce com a noite (DONATO, 1980, p. 23).

Os intentos expansionistas do Capitão Paulo e seu pequeno exército de jagunços eliminam as possibilidades de resistência dos posseiros menores e sem forças para confrontá-lo. Mas outros agentes, também grandes proprietários, levam ao extremo a luta por terras. Pequenas guerras civis se travam no Pontal. Posseiros e seus capangas formam milícias armadas para as disputas sangrentas. Este é o caso de Juventino. Se no passado era unido ao Capitão Paulo na condução da política local, visando a perpetuação do coronelismo na composição da política local, no presente da narrativa as disputas por terra os afastaram. Agora se colocam em campos opostos da batalha pelo domínio do lugar, como frações distintas dos setores proprietários daquele espaço.

Capitão Paulo é o indivíduo que submete tudo ao desejo de acumular riqueza, sob um aspecto é o colonizador ferrenho, engajado racionalmente na ampliação dos seus domínios, lembrando em sua ganância o personagem Paulo Honório, do romance S. Bernardo, de Graciliano Ramos. Juventino, por outro lado, é o proprietário hedonista, desprovido desta perspectiva da acumulação primitiva. Seus ganhos foram todos dissolvidos em jogos e na diversão. Falta a ele a racionalidade que permite converter a terra em valor de troca, ou em um acúmulo para o reinvestimento na produção. Os ganhos eram direcionados para o viver a vida. Tal mentalidade comporta uma noção tradicional que, conforme se ampliam as intenções do capitão Paulo, tende a se dissolver diante do processo civilizador violento e racionalizador, que decide no carteado a quem caberá se apropriar da terra como o uso da violência.

- Venho do Anastácio. Éramos onze a dividir o que restava para ser dividido. Não queremos brigar entre nós. Você pretende o Morro do Corote e eu também. A ordem da nossa irmandade é resolver tudo em paz. São quatrocentos alqueires que eu e você vamos decidir no baralho. Numa parada só, limpa e certa. Aceita?

Julião ensalivou as pontas dos dedos e os cantos da boca.

- Numa parada só!?

- Numa só! Não há tempo para mais.

As quatro testemunhas olhavam e bebiam (DONATO, 1980, p. 49). 
As diferenças entre os proprietários impedem a composição de uma "consciência de classe" entre os poderosos, que entram em brigas entre as frações que disputam as terras. Após um primeiro confronto, no qual Juventino é capturado e encarcerado a mando do Capitão Paulo, a narrativa passa a buscar exemplos de honra e lealdade, como se buscasse pesquisar as possibilidades de valores positivos da civilização em um ambiente tingido pelo interesse e a degradação.

Aparece aí a figura do sujeito de honra, orientado não pelos fins econômicos, mas por valores que preza como essenciais. É a lealdade e não o interesse econômico que garante a dedicação do "negro Crispim" à tarefa de libertar Juventino do cárcere. 0 primeiro tinha neste uma figura de reverência, sentia-se na obrigação de retribuir a camaradagem e o respeito do passado, sem esperar recompensa material para tanto.

Por outro lado, capitão Paulo não tem amigos, apenas relações impessoais e violentas, pois é motivado exclusivamente pelo interesse acumulativo. Juventino, também representante do mandonismo, inversamente, dispõe de respeito e amizades, pois é o adepto da pessoalidade, é um homem cordial. Na guerra entre ambos, novamente emerge o confronto entre 0 agente radical da acumulação, o empreendedor sem escrúpulos que percebe as oportunidades do progresso e o mandatário tradicional, cercado de relações pessoais de compadrio. A confrontação entre tradição e modernidade em um espaço que sofre um processo de crescimento econômico é expressa na composição destes personagens. Porém, estas relações são, sobretudo, formas distintas de dominação, que nas novas configurações que o progresso porta, não podem mais conviver.

A voz que se ouve em toda parte sussurra em ritmo de susto para quem quiser ouvir:

- Coisas terríveis vão acontecer! Quando os bodes se marram os cabritos é que se machucam. Muitas barbaridades estão a caminho! Agora já não basta mais para o Juventino e o Paulo. Um deles tem que ficar mandando na terra, o outro debaixo dela. Enquanto isso, os pobres é que penam (DONATO, 1980, p. 106).

Uma densa expectativa antecede o confronto entre os jagunços do Capitão Paulo e os de Juventino. 0 primeiro cercado de capangas pagos, de mercenários; o segundo contando com camaradas antigos e devedores de favores, ou solidários companheiros de farra. Neste ponto a natureza ressurge como paisagem e como cenário das ansiedades e violências.

Vai a lua cheia a meio caminho. Limpa, enorme, alegre. Suaviza o quieto agreste do sertão indormido. Procópio [capanga de Paulo] leva seus homens pra junto dos de Juventino. E Juventino espera com os seus os chegadiços. 
Tão próximos estão agora - com a Lua começando a descer na outra metade do céu, que uma palavra de paz, um grito de saudação seria bem ouvido de uma a outro (DONATO, 1980, p. 115).

0 ambiente bucólico convida à conciliação, aos acordos civilizados, à constituição de um pacto social. Não é isto, porém, que o desejo pela posse da terra busca. Uma pequena guerra civil se realiza entre os proprietários. 0 confronto, porém, não consegue eliminar Juventino, que é preso, pois Paulo o quer vivo para cumprir a humilhação pública. Contudo, Juventino consegue escapar com a ajuda de simpatizantes, sobretudo de "negro Crispim".

- É você, Piaçaba? Viu! 0 que mais eu podia fazer? Você também acha que é mau sinal e que me liquido se não dou um fim no Juventino, não é? Sim, sim, eu sei que é! 0 Juventino agora é uma lenda, a resistência dos posseiros, a esperança dos meus inimigos, o vingador dos que derrotei. Você sabe, não quis liquidar o Juventino só por querer e nem pela terrinha minguada que ele possuía. Não, senhor! 0 Juventino seria um exemplo. Agora que ele escapou a segunda vez todo mundo fala nele e ri de mim. Estou desgraçado se não der cabo dele. Você o que acha, hem, Piaçaba? (DONATO, 1980, p. 126).

A maioria dos personagens de Chão Bruto parece apenas cumprir a fatalidade dos destinos. Aos indivíduos são restritas as possibilidades de alternar os rumos de sua história, já que seguem as condicionalidades do meio e dos horizontes que ele delimita. A poucos é facultado o direito de escolher. A limitação do espaço converte as trajetórias sociais em destinos. Os indivíduos deixam de ser agentes para se converter em epifenômenos da estrutura de poder e dominação construída violentamente neste rural.

0 professor Caio ressurge, neste ponto, como aquele que arrisca alterar as balizas de sua vida, resgatar a autonomia diluída e seus compromissos com a "civilização", pondo em risco inclusive sua vida ao auxiliar o "negro Crispim" na tarefa de libertar Juventino das grades. As circunstâncias lhe ofereciam alternativas: ou denunciava Crispim ao Capitão Paulo e caía em suas graças, ou auxiliava na fuga e satisfazia sua consciência. Ao optar pela segunda, Caio almeja romper as limitações que o envolvem e, a partir disto, vive instantes de uma sensação de liberdade incomum em sua permanente angústia para com o meio.

Ao apresentar a justificativa de sua deliberação para Xaica, explicita, mesmo que titubeante, sua intenção de dissolver a limitação que envolve as relações naquele espaço e assumir uma posição de agente do processo, de exemplo intelectual e prático, 
apontando que existiria alguma possibilidade do indivíduo "escolher" os rumos de sua existência e não ser conduzido pelo meio físico e social.

- Fiz porque sou professor. Milhares de vezes tenho dito aos meninos que todos os homens são iguais, e não é justo que uns tomem aos outros a terra, a água, a casa. Milhares de vezes tenho dito que os fracos merecem proteção e os fortes exigem limitações. Tanto repeti essas coisas que acabei convencido. Mas nem sempre bastam as lições, muitas vezes são precisos exemplos. E então chega para o homem, o momento em que deve usar as mãos para praticar o que ensina (DONAT0, 1980, p. 122).

A ação do professor Caio é tingida de certo intento iluminista. Cansado de ocupar a posição idealista, transforma-se no agente concreto da mudança: os homens devem não apenas conhecer, mas transformar a realidade, pensa o jovem professor. Por outro lado, fica patente, na ótica do narrador, a inviabilidade do processo educativo, pois seus alunos vivenciavam e eram socializados no interior da limitação, o que os tornava imunes aos ensinamentos da ciência e da civilização.

Caio, com seu ato, leva adiante uma estratégia individual de ruptura com a restrição da vida social, já que falhou na construção de sujeitos civilizados por meio do ideal educativo. Não rompe o sistema coronelista/jagunço, apenas desvia momentaneamente seu curso. Sua rebelião está limitada a um ódio contido aos poderosos, não assumindo consequências de transformação social.

0 sertão endureceu-lhe o corpo, temperou-lhe a vontade, abriu-lhe os olhos, ensinou-0 a enxergar o horizonte, destapou-lhe os ouvidos para ouvir a chegada da noite, conhecer 0 correr das horas pelas vozes dos pássaros e a vontade do tempo pela feição do vento [...] mas pediram que cuidasse da escola e $\log 0$ o visgo do barranco alcançou-o. Tornara-se criatura do lugar. Odiara os odiosos, amara os pequenos e bons, perguntara todas as manhãs quais as novidades da gente e da terra. Sem posses para defender e sem desejos de conquistá-las, não encontrou um mundo para se incorporar, mas teve que construir o seu próprio (DONATO, 1980, p. 151-152).

0 ato de Caio, ajudando na libertação de Juventino, não significa a dissolução das violências na luta pela terra. Aos poucos, contudo, um modo de existência vai sendo superado. A autoridade local, com o processo de expansão das relações capitalistas vai sendo substituída gradualmente pela figura do Estado. Ao final da obra, os posseiros aparecem como uma espécie de rescaldo, fragmentos de sociabilidades anteriores, que se constituem como "impeditivos à ordem social capitalista", ao uso racional e econômico do rural. Porém, uma forma de modernização seletiva fragiliza, mas não elimina 0 
coronelismo. Ao contrário, pois a racionalidade de mercado a ele se associa e mesmo dele depende. Esta é a condição que o romance de Donato parece apontar.

- Capitão não pode com o Juventino. Os grileiros já não mandam tanto. Só falta um empurrão de braço forte e eles dão por terra. Sabem? 0 governo vem aí com força e com lei braba. Vai haver o diabo (DONATO, 1980, p. 127).

A percepção de que um sistema social específico encontra-se em dissolução, em processo de substituição, também é apresentada por meio das reflexões de Suindara, o velho morador da região que vislumbra os vários movimentos na vila, e que é o observador perspicaz das transformações em curso.

- Muita coisa acaba com o Juventino. Vão com ele, um pouco antes ou depois, todos os posseiros desvalidos, todos os grileiros sem recursos e sem apoio político, todos os que não conseguiram entrar para a irmandade. Acaba com ele o sossego de se viver nesses campos como touro alongado, comendo e bebendo à custa da natureza. Acaba 0 risco no cão à moda de divisa entre dois senhores...

- Para você é quase o fim do mundo?

- Pra mim só? A Sorocabana está aí e vai acabar com a boiadeira no lado paulista. Vem a estrada e erguem armazéns, fazem cadeias, mandam descarregar impostos sobre 0 trabalho, a casa, sobre os caminhos que 0 homem trabalhou e abriu. Estamos acabados. Enquanto a terra é disputada a gente pode esperar e mudar de lado quando o vento bater nas costelas. Mas quando a terra estiver dividida acaba-se a paciência e o pobre já não é mais nada (DONATO, 1980, p. 133).

0 fim do sistema jagunço e de um mundo de barbaridades, quase um centro orgânico da vida social no espaço construído pela obra, encerra uma forma particular de limitação das individualidades, mas não com o rural como um espaço de restrição à existência.

- Você pensa, velho Libêncio, que são cadáveres de homens que levamos aqui? Que nada! Quando botarmos sete palmos de terra sobre estes sujeitos, estamos acabando com uma raça, a dos grileiros.

Libêncio ouvia, de olhos fechados, sugando o lenço. Cuspiu o pano e gemeu um protesto:

- Asneira! Você acha que sim? Está enganado, acabamos com dois galos, mas há por aí muitos frangos prontos pro primeiro cocorico! Qual nada, a luta pela terra continua (DONATO, 1980, p. 141). 


\section{AS MULHERES E A CIVILIZAÇÃO}

É possível ainda apreender as formas narrativas da limitação em Chão Bruto acompanhando a condição feminina. As três mulheres que habitam o espaço do romance vivem, cada uma a seu modo e em condições distintas, as implicações de um ambiente que a tudo consome e limita. Laura, a esposa do Capitão Paulo, convive com a angústia de ter trocado a possibilidade do amor pela ascensão econômica conseguida em um casamento de conveniência. A prostituta Xaica busca o amor entre os muitos indivíduos que passam por sua casa, mas ele é fugidio. Já Sinhana é impedida de viver seu amor de fato com Lino por causa das disputas de terra e somente no final da trama realiza parcialmente sua paixão.

As mulheres em Chão Bruto são descritas como sensíveis, passionais, amorosas e românticas em oposição aos homens, apresentados como violentos, interesseiros e brutalizados. Não cabe aqui aprofundar a análise sobre as construções distintas de gênero às quais o romancista recorre para descrever as relações amorosas. Apenas registramos tal recurso. Basta dizer que o elemento feminino em Chão Bruto é por vezes exagerado em suas idealizações afetivas, talvez para cumprir o efeito de realçar, como contraponto, o ambiente hostil que caracteriza a trama e os personagens. Afinal, em espaços de dominação tradicional, como é o caso de Chão Bruto, o poderio masculino possui um efeito ainda maior no plano da dominação patriarcal, pois a guerra é aqui reservada aos homens. 0 feminino não chega a ser idealizado em tons de uma pureza telúrica. Elas não possuem "amor pela terra”, ao contrário, não compreendem todas aquelas violências. Mas o feminino é, na narrativa, o único agente no qual o amor ou os sonhos da paixão se fazem possíveis naquele "chão bruto". A oposição entre valores femininos e masculinos é construída na trama quase como símbolo da oposição entre a civilização e a barbárie. Observemos, para encerrar, a disposição das mulheres na trama.

Xaica possui uma espécie de pensão, onde serve comida, hospeda viajantes e por vezes entrega-se a um deles por dinheiro ou por prazer. É uma forma de conforto para os capangas e matadores que circulam pelas terras. Descobre a paixão ao conhecer Rui, o advogado que aporta no Pontal com intenções de se apropriar de terras. Contudo, este irá se revelar ao longo da trama incapaz de vislumbrar o amor para além das utilidades materiais que ele possa trazer. Ela não possui essa utilidade. Neste sentido, Xaica é substituída por Laura, a esposa de Paulo, e que logo passa a ser o alvo estratégico de Rui. Em Xaica subsiste o desejo de amar, mas ela é apenas um acessório aos interesses que caracterizam o lugar. Acaba por perceber a impossibilidade do amor frente às limitações que a cercam e se entrega afetivamente para Caio, que também se resignara à permanecer no Pontal.

Laura, por outro lado, revive as esperanças de experimentar o amor com a chegada de Rui. Passa a nutrir uma paixão pelo jovem advogado, mas resiste a se 
entregar como amante. 0 marido a ama, mas ama antes de tudo a terra, deseja possuir a terra em escala cada vez maior. Já Laura, a "moça da cidade", é apresentada como incapaz de amar a terra, pois com ela não possui vínculos telúricos. É muito mais incapaz ainda de retribuir ao amor do marido.

A presença de Rui restitui em Laura a idealização de uma paixão que ainda não vivera. Neste sentido, a morte de seu marido, Capitão Paulo, abre espaço para se entregar a Rui. Ao se casar com este, contudo, percebe que as motivações eram similares às do marido anterior e a paixão se dissolve: "- Agora, Laura, já não seria adultério. Disso é que você tinha medo, hem? (pergunta Rui) - Agora seria um dever (responde Laura)" (DONATO, 1980, p. 158).

É apenas em Sinhana - a "camponesa pura", criada de forma isolada da civilização, em contado apenas com a natureza e o trabalho na terra - que 0 amor se realiza. A filha do posseiro Libêncio nutre um grande afeto por Lino, o jagunço que inicia a trama como um matador de aluguel e busca abandonar sua condição ao se unir a Libêncio na defesa das terras, retomando sua condição originária de trabalhador rural. É a possibilidade do amor de Sinhana que o motiva. Mas a realização deste sentimento só é possível em outro contexto. A contenção que a violência e as disputas impõem à existência deixa interrompida a concretização do amor de ambos. É apenas com a suspensão das lutas que conseguem se casar. Sinhana é o elemento puro da trama. 0 trabalho duro, a aceitação passiva da autoridade do pai e uma paixão profunda por Lino são os conteúdos que a motivam. A propriedade da terra e o dinheiro não lhe interessam como valor em si, apenas a possibilidade de ficar junto com o pai e o noivo trabalhando na terra.

\section{CONSIDERAÇÕES FINAIS}

0 romance Chão Bruto cumpre assim uma reconstrução literária do processo de avanço do progresso e das dificuldades de se constituir um conjunto de relações mais "civilizadas" em um espaço organizado pelos interesses econômicos, tal como descrito na obra. A chamada modernização e o desenvolvimento, transcritos na chegada da ferrovia, conciliam-se com as formas atrasadas de dominação. Destas agitações econômicas emerge a reconfiguração da terra, mas não a superação do ambiente opressivo e limitador que o mundo rural demarca. Predomina, assim, um olhar resignado e dúbio diante das forças que se impõem.

0 uso que a obra faz de imagens e conceitos como civilização e progresso não possui intentos de celebração. Aqui tentamos destacar como a construção narrativa recorre a tais categorias em sua reconstrução de um espaço social por meio da ficção. Nesta elaboração o rural é tomado como espacialização física e social para a ação. Em 
tal espaço, porém, o processo civilizador se encontrava em fase embrionária e diante de grandes impeditivos. 0 progresso que encampava a tarefa de 0 realizar se associava à violência, o que colocava os termos da civilização em contradição com as práticas. De qualquer modo, a narrativa representa um capítulo interessante da associação feita em nossa história literária e intelectual entre o mundo rural e a ausência de civilização completa, entre 0 atraso e o progresso, o moderno e 0 arcaico.

\section{REFERÊNCIAS}

BOTELHO, André; BASTOS, Elide; BÔAS, Glaucia Villas (Org.). O moderno em questão: a década de 1950 no Brasil. Rio de Janeiro: TOPBOOKS, 2008.

CANDIDO, Antonio. 0 discurso e a cidade. São Paulo: Duas Cidade, 2004.

CANDIDO, Antonio. Os parceiros do Rio Bonito. São Paulo: Duas Cidades, 1975.

DONATO, Hernani. Chão bruto. São Paulo: Círculo do Livro: 1980.

EAGLETON, Terry. A ideia de cultura. São Paulo: Unesp, 2005.

ELIAS, Norbert. O processo civilizador. Rio de Janeiro: Ed. Jorge Zahar, 1994.

LIMA, Nísia Trindade. Um sertão chamado Brasil: intelectuais e representação geográfica da identidade nacional. Rio de Janeiro: Ed. Revan, 1999.

LÖWY, Michel; SAYRE, Robert. Revolta e melancolia : o romantismo na contramão da modernidade. Petrópolis: Vozes, 1995.

MICELI, Sergio. Intelectuais à brasileira. São Paulo: Companhia das Letras, 2001.

RIDENTI, Marcelo. Em busca do povo brasileiro. São Paulo: Record, 2001.

SANTOS, Robson. A terra desolada: representações do rural no romance brasileiro (1945-1964). 2011. Tese (Doutorado em Sociologia) - Unicamp, Campinas, 2011.

SOBREIRO FILHO, José. A Luta pela terra no Pontal do Paranapanema: história e atualidade. Geografia em Questão, Cascavel, v. 5, n. 1, p. 83-114, 2012.

STEFANI, Celia Regina Baider. O sistema ferroviário paulista - um estudo sobre a evolução do transporte de passageiros sobre trilhos. 2007. Dissertação (Mestrado em Geografia) - Universidade de São Paulo, São Paulo, 2007.

WILLIAMS, Raymond. Cultura. São Paulo: Paz e Terra, 2000.

WILLIAMS, Raymond. O campo e a cidade na bistória e na literatura. São Paulo: Companhia da Letras, 2011.

WILLIAMS, Raymond. Palavras-chave. São Paulo: Boitempo, 2007. 